\title{
Substitution Analysis of Farm Pattern of Soybean (Glycine max) with Sweet Citrus Fruit (Citrus sp.) and Dragon Fruit (hylocereus undatus) in Southern Banyuwangi
}

\author{
Muhammad Hazmi \\ Departement of Agrotechnology \\ UM Jember \\ Jember, Indonesia \\ mhazmi.hazmi@gmail.com
}

\author{
Syamsul Hadi \\ Dept. Agribusiness \\ UM Jember \\ Jember, Indonesia \\ syamsul.hadi@unmuhjember.ac.id
}

\author{
Edy Sutiarso \\ Dept. Agribusiness \\ UM Jember \\ Jember, Indonesia \\ esutiarso@yahoo.com
}

Abstract-The growing substitution patterns of soybeans into horticultural crops in Southern Banyuwangi caused the soy food stocks to decrease. This condition is possible to threaten the pillars of sustainable agriculture. This study was conducted to investigate any socio-economic factors that affect the farming substitution pattern. The purpose of this study are 1) to inventory the socio-economic factors that influence the substitution pattern of farming of soybeans into sweet oranges and dragon fruit, 2) to analyze their farming, and 3) to analyze the economic feasibility of the three farms. We employed descriptive and survey technique in this study. Data technical analysis used is descriptive analysis, Profit and $\mathrm{R} / \mathrm{C}$ ratio analysis. The results of this study revealed that 1) $77,5 \%$ of respondents farmer found soybean farming as economically less profitable than other crops commercialize, 2) soybean farming in the study area suffered average losses of up to IDR 1.796.957,84 per hectare and the sweet citrus fruit farming and the dragon have benefited large enough that the average IDR 51.058.201,83 per season per hectare, and 3) average $R / C$ ratio of 0,85 that soybean farming means are not economically feasible, and the sweet citrus fruit and dragon farming their each 4,95 and 3,81 which means the economically feasible. The policy implication is to make regulations to strengthen farmer's motivation so that farmers can increase their productivity through the application of the latest technology even though they survive citrus fruits and dragon fruit

Keywords: Socio-economic factors, and feasibility of Soybean, Sweet orange, and dragon fruit

\section{INTRODUCTION}

One of the agricultural commodities that concern the government and has a strategic role is the soybean commodity (Glycine max L.). The level of public consumption of soybeans is very large. Soybeans are one of the main commodities of beans that are the national mainstay since they are an important source of vegetable protein for food diversification in supporting national food security. District of Banyuwangi contributed $17.28 \%$ to East Java soybean production, while East Java soybean production contributed $42.51 \%$ to national soybean production. According to the Agriculture, Forestry and Plantation Office of District of Banyuwangi 1] that as the largest soybean producer in East Java, Banyuwangi farmers are able to harvest an average of 47313 tons with an average productivity of 18,35 quintals per hectare. Table 1 below shows that the development of soybean production in District of Banyuwangi increased during the period of 2008-2015 with an average of $3.16 \%$ per year with an average soybean production of 57,495.63 tons. Similarly, the level of soybean productivity in District of Banyuwangi also experienced a positive growth of $2.40 \%$. In 2008 soybean productivity reached $15.69 \mathrm{Qu} /$ ha and in 2015 reached $18.35 \mathrm{Qu} / \mathrm{ha}$.

Table 1. Harvested Area, Production and Productivity of Soybean Plant of District of Banyuwangi Period 2008-2015

\begin{tabular}{ccccrrr}
\hline $\begin{array}{c}\text { Yea } \\
\text { rs }\end{array}$ & $\begin{array}{c}\text { Land } \\
\text { Area } \\
\text { (Ha) }\end{array}$ & $\begin{array}{c}\text { Productio } \\
\text { n/Yield } \\
\text { (Tons) }\end{array}$ & $\begin{array}{c}\text { Produc } \\
\text { tivity } \\
\text { Qu/Ha } \\
\text { ) }\end{array}$ & $\begin{array}{c}\text { Develo } \\
\text { pment } \\
\text { of } \\
\text { Land } \\
\text { Area } \\
(\%)\end{array}$ & $\begin{array}{c}\text { Develo } \\
\text { pment } \\
\text { of } \\
\text { Produ } \\
\text { ctios } \\
(\%)\end{array}$ & $\begin{array}{c}\text { Develo } \\
\text { pment } \\
\text { of } \\
\text { Produc } \\
\text { tivity } \\
(\%)\end{array}$ \\
\hline 2008 & 28032 & 44739 & 15.69 & & & \\
2009 & 37677 & 64852 & 17.21 & 34.41 & 44.96 & 9.69 \\
2010 & 36912 & 64857 & 17.57 & -2.03 & 0.01 & 2.09 \\
2011 & 36068 & 66094 & 18.32 & -2.29 & 1.91 & 4.27 \\
2012 & 27257 & 53648 & 19.68 & -24.43 & -18.83 & 7.42 \\
2013 & 34021 & 67441 & 19.82 & 24.82 & 25.71 & 0.71 \\
2014 & 27857 & 51021 & 18.32 & -18.12 & -24.35 & -7.57 \\
2015 & 25784 & 47313 & 18.35 & -7.44 & -7.27 & 0.16 \\
\hline $\begin{array}{c}\text { Ave } \\
\text { rage }\end{array}$ & $\mathbf{3 1 , 7 0 1 . 0 0}$ & $\mathbf{5 7 , 4 9 5 . 6 3}$ & $\mathbf{1 8 . 1 2}$ & $\mathbf{0 . 7 0}$ & $\mathbf{3 . 1 6}$ & $\mathbf{2 . 4 0}$ \\
\hline
\end{tabular}

In the last six years, soybean productivity has continued to increase. Recently, it is the highest product in East Java, but the production and harvest area are fluctuating and tend to threaten the availability of soybean commodity. Farmers in Banyuwangi district, especially the southern part of many who divert soybean farming to commodities of sweet oranges and dragons. Farmers Exchange Rate for soybean commodities are experiencing significant decline due to no price guarantee from the government, input subsidies are revoked and the quality of the results of losing from imported products. In fact, local soybean prices range from IDR 7,500 - IDR $7,750 / \mathrm{kg}$ and this ice is still cheaper than imported soybean price which currently rises up to IDR $8,800 / \mathrm{kg}$.

Another contributing factor is that commodities of sweet oranges and dragons are economically much more viable than soybeans. During the period of 2008-2014 in Banyuwangi regency, the development of fruit production tends to increase significantly and on the other hand the growth of soybean crop has decreased in the same period. Regarding the development of harvested area, production and productivity of fruits in District of Banyuwangi during that period can be seen in Figure 1. 


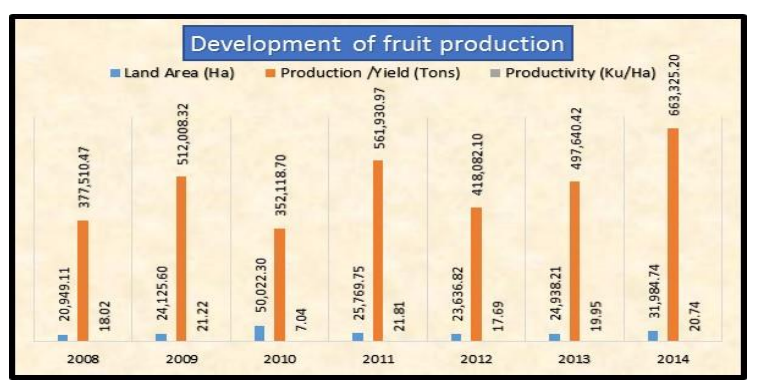

Figure 1. Development of Harvest Area, Production and Productivity of fruits at District of Banyuwangi Period 2008-2014

The phenomenon of agricultural substitution patterns as happened in Banyuwangi Regency is in accordance with the opinion [2] that there are many factors that influence farmers' decisions to process commodities on their own land. Factor of expectation of bigger profit from farming that will be chosen when compared with other farming form, plant age, stability of production, easy to whether or not the result is sold at any time, resilience of commodity to pest and disease. Meanwhile social factors include long-standing traditions and customs, neighboring farms, labor availability, educational levels and the like. The objectives of this research are 1) to inventory socio-economic factors that influence the substitution pattern of soybean farming into citrus and dragon fruit, and 2) to analyze the farming system to know the level of profit and economic feasibility of the three types of farming in South Banyuwangi Regency.

\section{METHODS}

\section{A. Research and Technique of Sample Determination and Data Collection}

The type of this research is descriptive quantitative and qualitative research. The method used in this research is survey method[3]. Sampling is done in multi stage cluster sampling .This sample is representative of a simple random population taken using the Slovin formula [4]. The data collection technique is done by interviewing respondents through depth interview technique to soybean, sweet orange and dragon fruit farmer. We also interviewed another related institution to obtain primary and secondary data.

\section{B. Location and Time of Study}

This research has been conducted in Pesanggaran, Purwoharjo, Siliragung, Bangorejo, Tegaldlimo, Tegalsari, and Muncar sub-districts which become the center of soybean, sweet orange and dragon production in District of Banyuwangi in 2016 [1]. This Study used purposive sampling to determine the location of this study on the consideration that some areas of the district is a production center that need to be examined with the area of seven large harvest in the District. Furthermore, from the sub-district sample is then determined one village sample by using puposive sampling. Furthermore, from the sample sub-district, one sample village was determined by puposive sampling based on the consideration that the village had the most population of soybean, citrus and dragon farmers in the sample subdistrict.

\section{Variable Observed}

1. Socio-economic factors are the factors that cause farmers to substitute farming patterns from soybean commodities to citrus and dragon fruit commodities.

2. Farm profitability is a variable to measure the success rate of farming that takes place by calculating farm profit

3. Cost efficiency is used to measure business feasibility economically by calculating benefit cost ratio.

\section{Data Analysis}

In order to inventory the socio-economic factors that cause farmers to substitute soybean farming into citrus and dragon fruit, a qualitative descriptive analysis is conducted where the results are presented in the frequency table in units (\%). Furthermore, the results of the analysis are interpreted in full based on the findings of facts in the field to then be drawn an inferential conclusion. Furthermore, to know the profitability level of soybean farm, sweet citrus fruit, and dragon fruit and its feasibility economically, then each analyzed by formula of profit and R/C Ratio [5]. Furthermore, the results of the two analyzes were then compared by using the average t-test differentiator

\section{RESULTS \& DISCUSSION}

A. Socioeconomic Factors Affecting Against Soybean Farming Substitution Pattern to Farming of Citrus Fruits and Dragons

The results show that there are several socio-economic reasons for farmers so that farmers replace rice and secondary crops into sweet oranges and dragon fruit in paddy fields, moor and yard, especially in the dry season.Several socioeconomic factors that encourage soybean farmers to substitute farming commodities to citrus and dragon fruit are: respondents were less interested in planting soybean commodities as they did because they saw the low profit factor of soybean farming (76\%) While as many as $16 \%$ of respondents assessed the price of cheap production and by $8 \%$ unproven uncertainty season factor. Another factor is the lack of motivation from the government to keep planting soybeans in order to meet domestic and family needs.

This is indicated by the results of the study indicating that only $21 \%$ of respondents who get government motivation will it, while $79 \%$ of other respondents never experienced the same thing. The results of this study are in accordance with the results of research in Jember District about the same context which also revealed that the factors that caused the weaker response of the farmers include: 1) most (54\%) of farmers respondents have the perception that Soybean farming economics is less profitable compared to other commodities; 2) as large (74\%) of farmers respondents are still traumatized with the past condition and there is no protection from the government and no floor price determination of soybean production [6].

Table 2 below also reveals that as many as $71 \%$ of respondents stated that planting citrus fruits and dragon-level advantages are more secure than planting soybeans. Nevertheless most $(21 \%)$ of the farmers stated that the 
decision was strongly influenced by other farmers to be substituted for farming on dragon and orange fruits. In addition, as many as $87 \%$ of respondents who substitute their commodities have reasoned that dragon fruit and orange cultivation are technically easier to apply than soybeans. During the harvesting period of citrus and dragon fruit farming, a small percentage of respondents $(35 \%)$ planted soybeans as intercropping plants because $85 \%$ of the sun still vegetative can illuminate soybean crops.

Table 2. Influential Socioeconomic Factors Against Farmers' Decisions Making Substitution Patterns of Farming Commodities in District of Southern Banyuwangi

\begin{tabular}{|c|c|c|c|c|}
\hline No & $\begin{array}{c}\text { Socio-Economic Factors } \\
\text { Influencing Farmers' } \\
\text { Responsibility Substitute } \\
\text { Farming }\end{array}$ & $\begin{array}{c}\text { Answer } \\
\text { Respondents }\end{array}$ & $\begin{array}{c}\text { Total } \\
\text { (Persons) }\end{array}$ & $\begin{array}{l}\text { Percenta } \\
\text { ge }(\%)\end{array}$ \\
\hline \multirow{3}{*}{1.} & \multirow{3}{*}{$\begin{array}{l}\text { The reason is no longer } \\
\text { interested in planting } \\
\text { soybeans as before }\end{array}$} & a. Low Profit & 29 & 76 \\
\hline & & $\begin{array}{l}\text { b. Season } \\
\text { Factor }\end{array}$ & 3 & 8 \\
\hline & & $\begin{array}{l}\text { c. Production } \\
\text { Price is } \\
\text { Cheap }\end{array}$ & 6 & 16 \\
\hline \multirow{2}{*}{2} & \multirow{2}{*}{$\begin{array}{l}\text { Motivation from the } \\
\text { government to keep soybean } \\
\text { growing to meet domestic } \\
\text { and family needs }\end{array}$} & $\begin{array}{l}\text { There is } \\
\text { (Stand) }\end{array}$ & 8 & 21 \\
\hline & & b. There is not & 30 & 79 \\
\hline \multirow{2}{*}{3.} & \multirow{2}{*}{$\begin{array}{l}\text { Planting soybeans requires } \\
\text { higher production costs } \\
\text { compared to dragon fruit and } \\
\text { orange cultivation }\end{array}$} & $\begin{array}{l}\text { a. There is } \\
\text { (Stand) }\end{array}$ & 9 & 24 \\
\hline & & b. There is not & 29 & 76 \\
\hline \multirow[t]{2}{*}{4} & \multirow{2}{*}{$\begin{array}{l}\text { Planting citrus fruits and } \\
\text { dragons are more profitable } \\
\text { than the soybean }\end{array}$} & a. There is & 27 & 71 \\
\hline & & b. There is not & 11 & 29 \\
\hline \multirow[t]{2}{*}{5} & $\begin{array}{l}\text { Switching to planting dragon } \\
\text { and orange fruit is a rational } \\
\text { decision and not because of }\end{array}$ & $\begin{array}{l}\text { There is } \\
\text { (Stand) }\end{array}$ & 30 & 79 \\
\hline & $\begin{array}{l}\text { trial and error or simply } \\
\text { joining other farmers }\end{array}$ & b. There is not & 8 & 21 \\
\hline \multirow[t]{2}{*}{6} & $\begin{array}{l}\text { The cultivation of dragon } \\
\text { fruit and oranges is }\end{array}$ & $\begin{array}{l}\text { a. There is } \\
\text { (Stand) }\end{array}$ & 33 & 87 \\
\hline & $\begin{array}{l}\text { technically easier to apply } \\
\text { than soybeans }\end{array}$ & b. There is not & 5 & 13 \\
\hline \multirow[b]{2}{*}{7} & $\begin{array}{l}\text { The cultivation of dragon } \\
\text { fruit and oranges is }\end{array}$ & a. There is & 32 & 84 \\
\hline & $\begin{array}{l}\text { financially lower in } \\
\text { production cost compared to } \\
\text { soybean farming }\end{array}$ & b. There is not & 6 & 16 \\
\hline \multirow{2}{*}{8} & $\begin{array}{l}\text { Dragon and orange fruit } \\
\text { products are prospective and }\end{array}$ & $\begin{array}{l}\text { There is } \\
\text { (Stand) }\end{array}$ & 38 & 100 \\
\hline & $\begin{array}{l}\text { more profitable than soy } \\
\text { products }\end{array}$ & b. There is not & 0 & 0 \\
\hline
\end{tabular}

\section{B. Analysis of Soybean Cultivation, Sweet Oranges and Dragon}

This section will explain the cost structure of soybean, orange and dragon farming practices based on variable and fixed costs in order to provide an overview of the comparison of cost usage in the three farms. The time of data extraction on soybean farmer respondents was done for the dry season and simultaneously data were collected on citrus and orange farmers in the fourth year. This means it is assumed that information on the cost structure, revenue and profit occurs simultaneously, ie during the dry season of 2015-2016 when the sweet orange and dragon fruit farming has passed the payback period dragon fruit farming is smaller than the economic age (15 years) ie two years Three months [9]. Meanwhile, the value of Pay Back Period or period of return on investment of citrus farming business in private only takes 3.67 years, and socially only takes 2.43 years [10].

The results of this study revealed that the variable cost structure of soybean farming was $44.79 \%$ or lower than the fixed cost $(55.21 \%)$ (Table 3) average production cost in soybean farming in the research area of IDR 5,524,996.11 per area of arable land or IDR 11,275,502.27 per hectare. The high use of fixed costs in farming activities is due to the fact that land leases reach a proportion of $45.88 \%$ compared to other fixed costs, where own or leasehold ownership status is a cost component to be accounted for, even though in real terms the respondents whose tenure is rented only $25 \%$. The calculation of the cost of farming is based on expert's opinion that the calculated costs are the fees charged to farming for the use of labor in the family, the depreciation of farm equipment and the cost of land lease [11].

This phenomenon suits the results of research in East Java, West java and South Sulawesi. Zakaria stated that agriculture in three agro-ecosystems are economically efficient and sufficiently competent as import substitution commodities [7] Increased farmer participation for soybean cultivation is constrained by the availability of superior and quality soybean seeds, high farming risks and the absence of guaranteed selling price of soybean by the government. Similarly, the result of research in Keerom Papua Regency concludes that the farmer trade system that tends to disadvantage local soybean farmers, soybeans cheaper import into the markets in the area and the price of fertilizers fluctuate and tend to rise are some of the threats Must be addressed promptly to ensure the creation of Indonesia's food security through the availability of sustainable local soybean [8].

Table 3. Cost Structure of Soybean Farming in District of Southern Banyuwangi per Hectare

\begin{tabular}{|c|c|c|c|c|c|c|}
\hline No & $\begin{array}{c}\text { Cost } \\
\text { Descriptions }\end{array}$ & Unit & Volume & IDR/Unit & Value (IDR) & $\begin{array}{c}\text { Percentage } \\
(\%)\end{array}$ \\
\hline A & $\begin{array}{l}\text { Variable } \\
\text { Cost: }\end{array}$ & & & & & \\
\hline \multirow[t]{6}{*}{1} & $\begin{array}{l}\text { Yield } \\
\text { Facility: }\end{array}$ & & & & & \\
\hline & a. Seed & $\mathrm{Kg}$ & 16,42 & $7,250.00$ & $119,020.83$ & 2,15 \\
\hline & $\begin{array}{l}\text { b. Urea } \\
\text { Fertilizer }\end{array}$ & $\mathrm{Qu}$ & 1,40 & $101,800,00$ & $142,520.00$ & 2.58 \\
\hline & $\begin{array}{l}\text { c. ZA/TSP } \\
\text { Fertilizer } \\
\text { d. Fruit }\end{array}$ & Qu & 0,50 & $100,000 ., 00$ & $50,000.00$ & 0.90 \\
\hline & $\begin{array}{l}\text { Gandusil dan } \\
\text { Leaf } \\
\text { Gundasil) }\end{array}$ & Qu & 1,56 & $50,888.89$ & $79,160.49$ & 1.43 \\
\hline & $\begin{array}{l}\text { e. Other } \\
\text { drugs }\end{array}$ & Ls & 2,00 & $74,857.14$ & $149,714.29$ & 2.71 \\
\hline \multirow[t]{2}{*}{2} & $\begin{array}{l}\text { Labors } \\
\text { (People's } \\
\text { work day) }\end{array}$ & PWD & 28,44 & $68,000.00$ & $1.934,183.67$ & 35.01 \\
\hline & & \multicolumn{2}{|c|}{ Sub Total } & & 2.474.599.29 & 44.79 \\
\hline B & Fixed cost: & & & & & \\
\hline 1 & $\begin{array}{l}\text { Depreciation } \\
\text { Fee Tool }\end{array}$ & Ls & 1,00 & $221, .271 ., 83$ & $221,271.83$ & 4.00 \\
\hline 2 & Land Tax & Season & 1,00 & $73, .125 .00$ & $73,125.00$ & 1.32 \\
\hline 3 & Land Rental & Season & 1,00 & $2.535,000.00$ & $2.535,000.00$ & 45.88 \\
\hline 4 & $\begin{array}{l}\text { Water } \\
\text { Resources }\end{array}$ & Season & 1,00 & $71,000.00$ & $71,000.00$ & 1.29 \\
\hline \multirow[t]{3}{*}{5} & $\begin{array}{l}\text { Group } \\
\text { Contributions }\end{array}$ & Season & 1,00 & 150.000 .00 & $150,000.00$ & 2.71 \\
\hline & \multicolumn{4}{|c|}{ Sub Total } & $3,050,396,83$ & 55.21 \\
\hline & \multicolumn{4}{|c|}{ Total } & $5,524,996.11$ & 100 \\
\hline
\end{tabular}

Table 3 illustrates that the use of variable costs in soybean farming in research areas is relatively high due to the high use of labor costs (IDR 68,000. - / Man's day) although most $(66.67 \%)$ of respondents did not do soil (TOT) Rice crops and there is only a small germination activity around the plot. 
Similarly, as many as $50 \%$ of respondents did not conduct irrigation activities due to paddy fields that since the beginning of the planting season has been irrigated water through the gutters that have been made. In addition, most farmers rarely planted soybean seeds with a depth of $2-3 \mathrm{~cm}$, but were done by random scattering system or randomly.

In the use of production facilities which include first fertilization, second fertilization and second spraying is done only by respective respondents as much as $25 \%, 8.33 \%$ and $50 \%$ with the average amount of allocation Urea Fertilizer, KCL, Drugs and Gandasil Fruit / Gundasil Leaves of each 1.4 quintals, 0,5 quintals, 1,56 liters and 2 liters per cultivated land area or 2,86 quintals each, 1,02 quintals, 3,17 quintals and 4 liters per Hectare. Nevertheless, the allocation of production facilities conducted by respondents exceeds the recommendation, which according to the recommendation of the [12] that the dosage of fertilizer used for soybean farming is about $50 \mathrm{~kg}$ urea, $150 \mathrm{~kg}$ NPK Fertilizer, SP36 $150 \mathrm{Kg}$ Fertilizer, Urea Daun $50 \mathrm{Kg}$ and $100-150 \mathrm{~kg}$ of $\mathrm{KCl} / \mathrm{ha}$ given entirely at planting time. The use of soybean seeds by farmers respondents is still under the recommendation, that is as much as $16,42 \mathrm{~kg}$ per area of arable land $(33.5 \mathrm{Kg} /$ hectare). Whereas according to the recommendation of [12] that the use of soybean seeds superior with the power to grow $85 \%$ as much as $40-50 \mathrm{~kg} / \mathrm{ha}$ seed.

(IDR 2,098,013.47) per area of cultivated land per season $(0,79 \mathrm{ha})$ in the fourth year for land preparation activities and concrete pile of host, Maintenance, irrigation

Table 4. Fruit and Dragon Fruit Farming Cost Structure in District of Southern Banyuwangi per unit (0.79 ha) per Season of Fourth Year

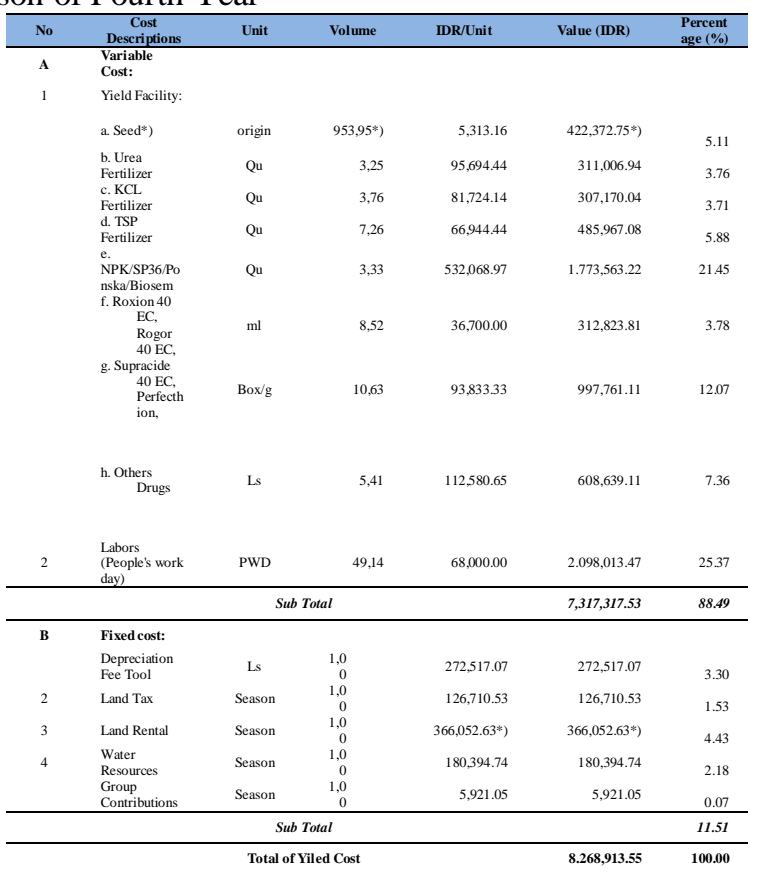

Description: *) The cost value of seed production facilities and the value of the land rent is actually IDR 5,068,472.99 and IDR 4,392,631.58 calculated in the fourth year and per season, then divided by 4 years and 3 seasons.

In contrast to the cost structure of soybean farming, the cost structure of sweet orange and dragon farms in the study and harvesting. The amount of contribution of expenditure for labor is still lower than the result of research of Jeruk Siam in Jember Regency by [10], that is equal to $29 \%$. Therefore, the high total cost of farming of these two types of farming in the fourth year is still lower than the result of research [13] in Padang Pariaman District that the average total cost of dragon farm production reaches IDR 107,064,423.33 per hectare per Year (in the fourth year). Similarly, the average cost of citrus fruit farming in the research area is much lower than the result of [10] in Jember Regency. The average total cost of citrus farming is IDR $351,154,546$ per hectare per year.

Table 4 shows that soybean farming in the research area suffered losses of up to IDR $1,796,957.84$ per hectare. This is due to the relatively high production cost, which is IDR $11,231,530.49$ per hectare where the fixed cost of production occupies the highest portion (IDR 6,155,429.39). This is due to the high cost of land rent with a value of IDR 5,200,000. per hectare per season, while the cost of depreciation tools reach IDR 350,300 per hectare. As for variable costs, the highest value was contributed by the sacrifice for the average labor cost of IDR 3,947,313.62 per hectare and the average cost of production facilities was IDR 1,128,787.48, - per hectare. Adapaun labor used by the respondents in addition to using labor in the family also from outside the family. The prevailing wage rate in the research area is male worker Rp 68,000 / man's day and female laborer IDR 50,000 / man's day. Activities in soybean farming include cultivation of land planting, fertilizing, spraying, weeding and harvesting area, where the variable cost per area of arable land per season $(0,79$ ha) in the fourth year had a proportion of $88.49 \%$ (IDR 7,317,317.53) and a fixed cost of $11.51 \%$ (IDR 951,596.02) as shown in Table 3. The highest cost of variable cost component is used for labor wages reaching $25.57 \%$

The condition of soybean production amount as shown in Table 4 is relatively the same as 14] that in Ciranjang District Cianjur Regency, West Java, the average production per hectare is 1370.97 kilograms with the yield of 1,37 tons per hectare. However, in terms of the benefits of soybean farming in the research area, the condition is also very contradictory with the results of research in Jember District which concluded that the average profit reached IDR 4,487,125.76 per hectare. The average rate of profit is actually relatively moderate when compared with the cost of sacrifices incurred by farmers respondents [6].

Table 5. Production, Production Value and Profit of Soybean Farm in District of Southern Banyuwangi per Hectare

\begin{tabular}{clcr}
\hline No & Descriptions & Unit & Value/Volume \\
\hline 1 & Yield & IDR & $1,420.51$ \\
2 & Variable Cost & IDR & $5,076,101.10$ \\
3 & Fixed Cost & IDR & $6.155,429.39$ \\
4 & Product Price & IDR /Kg & $6,641.67$ \\
5 & Revenue & IDR & $9.434,572.65$ \\
6 & Profit & IDR & $(1,796,957.84)$ \\
\hline
\end{tabular}

Meanwhile, in Table 5 it was revealed that the results of benefit analysis on citrus and dragon fruit farms in the study area in the fourth year per hectare per season gained considerable profit on average of IDR 51,058,201.83 with 
average production cost IDR 21,459,350.80 and production value of IDR 72,517,552.63 with average product price (orange and dragon) of IDR 6,372.37 per kg. The profit value is still lower than the results of the research which concluded that citrus farming profits based on current value in private are IDR 221,542,727.00 per hectare per year or IDR $73,847,576$ per season per year with value Pay Back The citrus farming period in private only takes 3.67 years [10].

Table 6. Production, Production Value and Profit of Citrus and Dragon Farming at District of Southern Banyuwangi per Hectares

\begin{tabular}{clcr}
\hline No & Descriptios & Unit & Value/Volume \\
\hline 1 & Yield & IDR & $11,380.00$ \\
2 & Variable Cost & IDR & $15,153,662.51$ \\
3 & Fixed Cost & IDR & $6,305,688.29$ \\
4 & Product Price & IDR /Kg & $6,372.37$ \\
5 & Revenue & IDR & $72,517,552.63$ \\
6 & Profit & IDR & $51,058,201.83$ \\
\hline
\end{tabular}

C. Economic Analysis for Measuring the Feasibility Level of Soybean Farming, Sweet Orange Fruit and Dragon

At the feasibility level of soybean farming with sweet orange and dragon fruit in the study area as presented in Table 7 can be described that the average $\mathrm{R} / \mathrm{C}$ ratio of soybean farming is 0,85 . This means that each production cost expenditure of IDR 1 , it will receive revenue of IDR 0,85 which means it is not economically feasible to proceed. This condition is not in line with the results of which concluded that the average $\mathrm{R} / \mathrm{C}$ ratio in Jember regency reaches a value of 1,83 , even as much as $46 \%$ of farmers respondents reach R/C Ratio > 2 [6]. Similarly, study on Analysis of Farming and Soybean Practice in Ciranjang Subdistrict, Cianjur Regency, West Java, revealed the R/C ratio obtained by farmers harvesting old pods $(1,35)$ and young harvested farmers $(1,27)$. Even more extreme results of research [2] in District Sukorejo Ponorogo revealed that soybean farming and rice fields are equally efficient, for soybean farming wetland efficiency level 2,52 [14].

Table 7. Result of Economic Feasibility Analysis on Farming of Fruits Citrus and Dragon in District of Southern Banyuwangi

\begin{tabular}{rlrr}
\hline No & Description & $\begin{array}{c}\text { Soybean } \\
\text { Farming }\end{array}$ & $\begin{array}{c}\text { Citrus and } \\
\text { Dragon } \\
\text { Farming }\end{array}$ \\
\hline 1 & Revenue (IDR) & $7,814,273.50$ & $72,015,567.98$ \\
2 & Productios Cost (IDR) & $11,333,325.36$ & $21,459,350.80$ \\
3 & R/C Ratio & 0.69 & 3.38 \\
\hline
\end{tabular}

Table 7 also shows that the average $\mathrm{R} / \mathrm{C}$ ratio of citrus fruit and dragon fruit farming is 3.38 which means it is economically feasible to continue and if between the two are decomposed, the average $\mathrm{R} / \mathrm{C}$ ratio of citrus fruit is 4.95 and Average R/C dragon fruit ratio of 3.81. This means that sweet orange farming in the research area has more economic feasibility than dragon fruit along with higher production price than dragon fruit besides the amount of productivity, where the average productivity of citrus fruit reaches 13.49 and dragon fruit only 4.48 . If compared to $\mathrm{R} / \mathrm{C}$ ratio orange (citrus) farming in farmer field in tidal land, then farming in this research area is more feasible to be cultivated than result of [15] research because $\mathrm{R} / \mathrm{C}$ ratio of sweet orange farming in Barambai Muara Village Marabahan Sub District Barito Regency Kuala value is 3.19. Meanwhile, the results of the analysis of dragon fruit cultivation in Samboja by [13] showed a $\mathrm{R} / \mathrm{C}$ ratio of 1.42 , which means lower than in this study area. This condition indicates that the dragon fruit farming business in the research location is more feasible to be developed, especially if the farmers use their own land and minimize the use of labor as well as the support of adequate equipment and production facilities. Similarly, the results of [16] shows economically the exploitation of dragon fruit plants in East Java is very feasible, this is indicated by the end of the fourth year $\mathrm{R} / \mathrm{C}$ ratio of 2.76 .

\section{CONCLUSION}

1. Socio-economic factors that encourage soybean farmers to substitute farming for citrus fruit and dragon include: respondents factor less interested to plant soybeans $(76 \%)$ respondents perceptions of soybean farming profits low due to cheap production prices (16\%), Respondents have never gained motivation from the government $(79 \%)$ and seasonal factors are uncertain $(8 \%)$.

2. Structure of production cost in soybean farming in research area average as much as IDR 11,275,502.27 per hectare consisting of variable production cost as much $44.79 \%$ and fixed production cost equal to $55.21 \%$. The production cost structure of sweet orange and dragon farms in the study area averaged IDR 21,760,298.82 per hectare per season in the fourth year. Furthermore, soybean farming in the research area suffered losses of up to IDR $1,796,957.84$ per hectare and in sweet orange and dragon fruit farms in the study area in the fourth year per hectare per season earned an average profit of IDR $51,058,201.83$.

3. Average $\mathrm{R} / \mathrm{C}$ ratio of soybean farming is 0.69 which means economically not feasible, and average $\mathrm{R} C$ ratio of citrus fruit and dragon farming 3.38 with description average $\mathrm{R} / \mathrm{C}$ ratio of citrus fruit 4.95 and the average $\mathrm{R} / \mathrm{C}$ ratio of dragon fruit 3.81 which means it is economically feasible.

\section{ACKNOWLEDGMENTS}

We thank the Directorate of Research and Community Service - Directorate General for Higher Education Indonesian Ministry of Research and Higher Education through a Research Grant Program to support this research through the Second Year Scheme so that the writing of this scientific article can be completed and used to attend the FANRes international conference at UMY Yogyakarta on September 12-13 ${ }^{\text {th }}, 2018$.

\section{REFERENCES}

[1] Anonymous, Dinas Pertanian, Kehutanan dan Perkebunan Kabupaten Banyuwangi., November 25, 2015. [Online] Available: Jaringnews.com and Tempo.com [Accessed: August 10, 2016]. 
[2] Sulastri, S., Yuliati, Y., and Soemarno,. Analisis Usahatani Kedelai (Glycine max L.) yang Berkelanjutan di Kecamatan Sukorejo Kabupaten Ponorogo. In Thesis on Master Program of Environmental Resource Management and Post Graduate Development of Brawijaya University Malang, Faculty of Agriculture, Brawijaya University of Malang, January, 2012. [Online]. Available: Https://marno.lecture.ub.ac.id [Accessed: July 15, 2016.

[3] Singarimbun dan Effendi, S., Metode Penelitian Survei. Jakarta: LP3ES. 1987.

[4] Umar Husein, Desain Penelitian Manajemen Strategik. Jakarta: Penerbit PT Rajawali Grafindo Persada,2010.

[5] Hernanto, F., Ilmu Usaha Tani. Jakarta: Penebar Swadaya, 1996

[6] Hadi, S., and Wijaya, Faktor Melemahnya Respon Petani Terhadap Usahatani Kedelai (Clicine max.) di Kabupaten Jember, Inovasi Teknologi Lahan Suboptimal untuk Pengembangan Tanaman Aneka Kacang dan Umbi Mendukung Pencapaian Kedaulatan Pangan. . pp: 355 - 363, May 25, 2016.

[7] Zakaria A., K., Sejati W.K., and Kusttiari R., Analisis Daya Saing Komoditas Kedelai Menurut Agro Ekosistem: Kasus di Tiga Propinsi di Indonesia. Agro Economic Journal, Vol 28, No01, PP: 21 - 37. 2010.

[8] Rante, Y. (2013). Strategi Pengembangan Tanaman Kedelai untuk Pemberdayaan Ekonomi Rakyat di Kabupaten Keerom Propinsi Papua. In the Journal of Management and Entrepreneurship, 15 (01): 75 - 88.

[9] Tiyas, A., Setiawan, I., G., Putra, A., and Dewi, I, AL., Analisis Finansial Usaha Peternakan dan Buah Naga Merah (Hylocereus costaricensis) (Studi Kasus di Kelompok Tani Desa Berbuah Naga Kabupaten Sambirejo Kecamatan Bangorejo Kabupaten Banyuwangi). E-Journal of Agribusiness and Agro. Vol 4, No.5, Pp. 402 - 411. December, 2015.

[10] Sayekti, A., L., and Zamzami, L., Analisis Keunggulan Komparatif dan Kompetitif Jeruk Siam di Sentra Produksi, Widyariset, Vol 14, No 1, pp. 1-9, 2011.

[11] Soekartawi, Analisis Usahatani. Jakarta: Universitas Indonesia Press. 2006.

[12] Directorate General of Food Crops.,. Pedoman Teknis Pengelolaan Produksi Kedelai. Jakarta: Ministry of Agriculture. 2015.

[13] Gusti RY,.. Analisis Usaha Tani Buah Naga Daging Super Merah (Hylocereus costaricencis) sampai Tahun Ke-4 di Kabupaten Padang Pariaman. Thesis. University of Andalas, Padang, April 12, 2014. [Online]. http://repository.unand.ac.id/id/eprint/19789. [Accessed: July 09, 2016]

[14] Meryani, N., Analisis Usahatani dan Tataniaga Kedelai di Kecamatan Ciranjang, Kabupaten Cianjur, Jawa Barat. Thesis. Faculty of Agriculture. Bogor Agricultural Institute, Bogor. [online]. Available: https://repository.ipb.ac.id/bitstream [Accessed: July 09, 2016]

[15] Zuraida, R., Usahatani Jeruk Mendukung Pendapatan Petani Pada Lahan Pasang Surut di Kalimantan Selatan. (Kasus di Desa Barambai Muara Kecamatan Marabahan Kabupaten Barito Kuala). South Kalimantan Agricultural Technology Assessment Center. UNINTERESTING. Vol 9, No, 1, pp: 19 - 24. October, 2012

[16] Soelistyari HT, Siniati K, Lema B, Utomo WH. (2012). The Prospect of dragon fruit development in East Java. Proceedings Seminar and Exposure Technology Assessment Results AIAT East Java. pp: 333 - 340, July $9-10,2012$. 